\title{
Sex-related Differences in Gastrin Release and Parietal Cell Sensitivity to Gastrin in Healthy Human Beings
}

\author{
M. Feldman, C. T. Richardson, and J. H. Walsh, Medicine and Research \\ Services, Veterans Administration Medical Center, Dallas, Texas 75216; \\ Medicine and Research Services, Veterans Administration Medical Center, \\ West Los Angeles, California 90073; Department of Internal Medicine, \\ University of Texas Health Science Center, Dallas, Texas 75235; Department \\ of Internal Medicine, University of California at \\ Los Angeles, California 90024
}

\begin{abstract}
A B S T R A C T We compared serum gastrin concentrations and gastric acid secretion basally and in response to a mixed meal in age-matched women and men. Women had significantly higher basal serum gastrin concentrations $(P<0.01)$ and two- to threefold higher food-stimulated serum gastrin concentrations ( $P$ $<0.001$ ) than men. Basal and food-stimulated serum gastrin concentrations in women did not fluctuate significantly during the menstrual cycle. Sex-related differences in food-stimulated serum gastrin concentrations were not due to differences in antral $\mathrm{pH}$ because $\mathrm{pH}$ after the meal in women and men had been kept constant at 5.0 by in vivo intragastric titration with sodium bicarbonate.

Studies using an antibody that reacts only with potent gastrin heptadecapeptide species (G-17-I and II) indicated that women also had threefold higher serum G-17 concentrations after the meal than men ( $P$ $<0.005)$. Elevated serum G-17 concentrations after the meal in women were due to increased release of G-17 rather than slower clearance of G-17 from the circulation.

Despite elevated serum gastrin concentrations in response to food, women secreted approximately the same amount of acid relative to their maximal secretory capacity as men. Furthermore, during exogenous G-17 infusion, which led to identical serum gastrin concentrations in women and men, the dose-response curve for acid secretion in women was shifted significantly to the right of the G-17 dose-response curve in men $(P<0.02)$. The dose of G-17 that stimulated
\end{abstract}

Address reprint requests to Dr. Feldman, Veterans Administration Medical Center, Dallas, TX.

Received for publication 26 May 1982 and in revised form 24 November 1982. half of peak acid secretion was two to three times higher in women than in men, reflecting significantly reduced sensitivity of parietal cells to gastrin in women $(P<0.05)$. Our studies suggest that, compared with men, women release greater amounts of gastrin but are at the same time less sensitive to stimulation of acid secretion by gastrin.

\section{INTRODUCTION}

Because gastric acid secretion is stimulated by the hormone gastrin, we have been interested in factors that regulate the release of gastrin from $\mathrm{G}$ cells in humans. In reviewing data collected over the past 10 years, we observed that women had two- to threefold higher food-stimulated serum gastrin concentrations than men of the same age. Since this unexpected finding was made retrospectively and since sera had not always been measured in the same gastrin assay, a prospective study was then designed to compare basal and foodstimulated serum gastrin concentrations and acid secretion in another group of age-matched healthy women and men. Parietal cell sensitivity to gastrin was also compared in women and men during exogenous infusion of human gastrin heptadecapeptide (G-17). ${ }^{1}$

\section{METHODS}

Studies were approved by a Human Research and Review Committee. All subjects gave written informed consent prior to participation in these experiments.

Subjects. 41 healthy volunteers (15 women, 26 men) were studied prospectively after a 12 -h fast. No subject was pre-

\footnotetext{
${ }^{1}$ Abbreviations used in this paper: $\mathrm{BAO}$, basal acid output; $D_{50}$, dose needed to stimulate half of peak acid secretion; G-17, gastrin heptadecapeptide; $K_{\mathrm{e}}$, disappearance constant; PAO, peak acid output.
} 
selected for study in any way and none had previously participated in studies in our laboratory. 12 women were premenopausal and 3 were postmenopausal (one spontaneously, one after hysterectomy, and one after hysterectomy plus bilateral oophorectomy). One of these three postmenopausal women was receiving estrogen replacement therapy. 3 of the 12 premenopausal women were taking oral contraceptives. Data were not significantly affected if postmenopausal women or women receiving oral contraceptives (or both) were excluded from analysis. Ages of the women ranged from 24 to $50 \mathrm{yr}$ (median, $27 \mathrm{yr}$ ) and ages of the men from 23 to $48 \mathrm{yr}$ (median, $27 \mathrm{yr}$ ).

Basal acid output (BAO) and peak acid output (PAO). BAO and PAO were measured in each subject by standard nasogastric tube aspiration methods $(1,2)$. PAO was stimulated by a subcutaneous injection of either $6 \mu \mathrm{g} / \mathrm{kg}$ pentagastrin (Peptavlon, Ayerst Laboratories, New York) or 40 $\mu \mathrm{g} / \mathrm{kg}$ histamine (histamine phosphate, Eli Lilly \& Sons, Inc., Indianapolis, IN). Previous studies have shown that these doses of pentagastrin or histamine produce comparable maximal acid secretory rates (3).

Meal studies. On a separate day, food-stimulated serum gastrin concentration and acid secretion were measured simultaneously in 27 subjects ( 11 women, 16 men) after infusing a $600-\mathrm{ml}$ homogenized meal into the stomach through a nasogastric tube (4). The meal consisted of $142 \mathrm{~g}$ ground lean cooked sirloin steak, $28 \mathrm{~g}$ bread, $5 \mathrm{~g}$ butter, and water. Thus, the meal contained $39 \mathrm{~g}$ protein, $30 \mathrm{~g}$ carbohydrate, $30 \mathrm{~g}$ fat and $546 \mathrm{kcal}$ (as estimated from standard dietary tables). The meal had an osmolality of $138 \mathrm{mosmol} / \mathrm{kg}$ and had been adjusted with $0.1 \mathrm{~N} \mathrm{HCl}$ to a $\mathrm{pH}$ of 5.0. For 120 min after infusion of the meal, intragastric pH was kept constant at 5.0 and acid secretion measured by in vivo titration with $0.3 \mathrm{~N} \mathrm{NaHCO}_{3}$ (4). Acid secretion in response to the meal was expressed as a percentage of PAO in each subject to correct for a lower maximal acid secretory capacity in women than men.

G-17 infusion studies. To compare parietal cell sensitivity to gastrin in women and men, the effect of pure synthetic human G-17 on gastric acid output measured by aspiration and serum gastrin concentration was tested in 19 subjects ( 9 women and $10 \mathrm{men}$ ). After a $30-$ or $90-\mathrm{min}$ basal period during which $0.15 \mathrm{M} \mathrm{NaCl}$ was infused intravenously, a solution of G-17 dissolved in $0.15 \mathrm{M} \mathrm{NaCl}$ and containing $1 \%$ human albumin was infused intravenously at doses of 0.6 , $1.5,3.7,9.2$, or $23.1 \mu \mathrm{g} / \mathrm{h}$ (Imed infusion pump 922, IMED Corp., San Diego, CA).

In 11 subjects, G-17 doses of $1.5,3.7,9.2$, and $23.1 \mu \mathrm{g} / \mathrm{h}$ were infused for $45 \mathrm{~min}$ each on a single day in a stepwise fashion. At the end of the $23.1-\mu \mathrm{g} / \mathrm{h} \mathrm{G}-17$ infusion, the infusion pump was shut off and additional sera were obtained after $2,5,10,15,20$, and $30 \mathrm{~min}$ in order to compare the half times $\left(t_{1 / 2}\right)$ for disappearance of gastrin from the circulation (5). In eight other subjects, G-17 doses of $0.6,1.5$, 3.7 , and $9.2 \mu \mathrm{g} / \mathrm{h}$ were infused for $45 \mathrm{~min}$ each on separate days in random order. Thus, each of the 19 subjects received $1.5,3.7$, and $9.2 \mu \mathrm{g} \mathrm{G}-17 / \mathrm{h}$. Basal-subtracted acid secretory responses to each G-17 dose ( $\mathrm{mmol} / 45 \mathrm{~min}$ ) were then expressed as a percentage of PAO.

Serum gastrin measurement. Blood specimens were obtained from indwelling intravenous catheters at times indicated in Results. In G-17 infusion studies, blood was obtained from an intravenous catheter that had been placed into the arm opposite the G-17 infusion site.

Sera, obtained by centrifugation, were coded and shipped on dry ice from Dallas to Los Angeles for assay. All samples were tested in duplicate by radioimmunoassay. Total im- munoreactive serum gastrin concentration was measured using antibody 1296, a rabbit antigastrin prepared by immunization with gastrin conjugated to bovine serum albumin, at a final dilution of $1: 300,000$. Prior testing established that gastrin heptadecapeptides (G-17-I and G-17-II) and big gastrins (G-34-I and G-34-II) were both measured with this antibody, G-34 being about two-thirds as potent as G-17 on a molar basis (6). All sera from the meal studies were run in the same assay with an intraassay variation of $<7 \%$. In the G-17 infusion studies, sera were run in two separate assays due to the large number of samples. Interassay variation was $<21 \%$.

In the meal studies, we also measured serum G-17 concentrations using antibody $\mathbf{L} 6$, an antibody that specifically reacts with G-17 and not with other species of gastrin $(7,8)$. In addition, sera were reassayed for total gastrin simultaneously with antibody 1296 using the same $I^{125}$ label and G17 standard as in the L6 assay. The difference between total gastrin response and G-17 response was assumed to represent non-17 gastrin species, primarily big gastrins (7).

Statistics. Data are expressed as mean \pm 1 SEM. Average gastrin rises in response to the meal (in picograms per milliliter) were calculated by dividing the integrated gastrin response (9) by $120 \mathrm{~min}$. Differences in mean values between women and men were determined by two-tailed Student's group $t$ test. Differences in median values were determined by the median test. $P$ values $<0.05$ were considered statistically significant.

$t_{1 / 2}$ for G-17 was calculated for each of 11 subjects after cessation of intravenous G-17 infusion $(23.1 \mu \mathrm{g} / \mathrm{h})$. Basal gastrin concentrations were subtracted and the regression of the natural logarithm of rise in serum gastrin vs. time (in minutes) was computed to yield the slope which, with change of sign, is equal to the disappearance constant, $K_{e}(5) . t_{1 / 2}$ was calculated from the equation: $t_{1 / 2}=\operatorname{Ln} 2 / K_{e}$.

\section{RESULTS}

\section{Meal studies}

Just before the meal, women had significantly $(P$ $<0.01)$ higher mean basal serum gastrin concentrations than men (Fig. 1, left). Furthermore, women had two- to threefold higher mean serum gastrin concentrations after the meal than men. The average gastrin rises were $53 \pm 10 \mathrm{pg} / \mathrm{ml}$ in women and $19 \pm 2 \mathrm{pg} / \mathrm{ml}$ in men $(P<0.001)$. Despite elevated serum gastrin concentrations, women secreted approximately the same amount of acid in response to the meal as men when expressed as a percentage of peak acid output (Fig. 1, right).

As shown in Fig. 2 (left), the G-17 response to the meal (using antibody L6) was also significantly higher in women than men. The average G-17 rise for the $120 \mathrm{~min}$ was $38 \pm 9 \mathrm{pg} / \mathrm{ml}$ in women and $11 \pm 2 \mathrm{pg} / \mathrm{ml}$ in men $(P<0.005)$. Of the total gastrin response to the meal (Fig. 2, center), potent G-17 species accounted for $\sim 62 \%$ in the women and $55 \%$ in the men. The non-17 gastrin response to the meal (i.e., the total gastrin response minus the $\mathrm{G}-17$ response) was also significantly greater after the meal in women than men 
GASTRIN $(\mathrm{pg} / \mathrm{ml})$

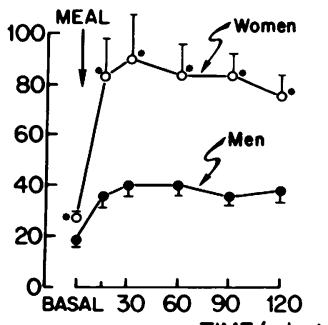

TIME (minutes)

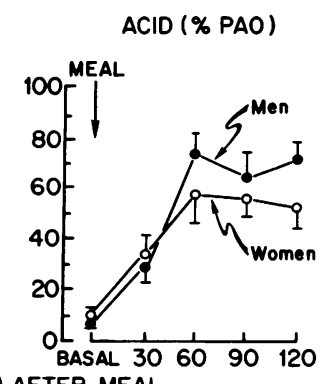

Figure 1 Mean ( \pm SE) basal and food-stimulated serum gastrin concentration (left) and acid secretion (right) expressed as a percentage of peak acid output (PAO) in 11 healthy women and 16 healthy men studied prospectively. Total immunoreactive serum gastrin concentrations were all measured in the same assay using antibody 1296 . 'Significant $(P<0.05)$ differences between women and men. Peak acid output averaged $28.6 \pm 2.7 \mathrm{mmol} / \mathrm{h}$ in women and $33.0 \pm 2.3$ $\mathrm{mmol} / \mathrm{h}$ in men.

(Fig. 2, right). The non-17 gastrin rise averaged $24 \pm 8$ $\mathrm{pg} / \mathrm{ml}$ in women and $9 \pm 2 \mathrm{pg} / \mathrm{ml}$ in men $(P<0.05)$.

In studies with the intragastric meal described above, we noted that increased serum gastrin concentrations occurred in women who were in the early, middle, or latter parts of their menstrual cycles. To further evaluate relationships between the menstrual cycle and serum gastrin concentration, six women were studied prospectively on three occasions, on day 1 , day

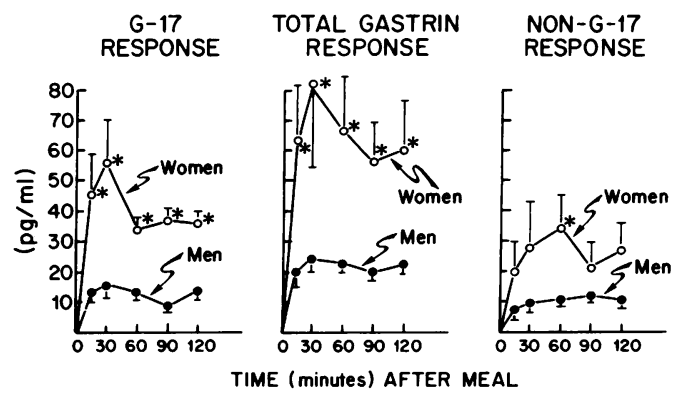

Figure 2 Mean ( \pm SE) basal-subtracted G-17 (left), total (center), and non-17 (right) gastrin responses to an intragastric meal in 11 healthy women and 15 healthy men studied prospectively. Antibody L6 was used to measure G-17 and antibody 1296 was used to measure total gastrin. These two antibodies were tagged with the same $I^{125}$ label and assays were run simultaneously using the same G-17 standard. Thus, sera that had been assayed for total gastrin using antibody 1296 (Fig. 1, left) were reassayed for total gastrin in conjunction with G-17 measurement. The difference between the total gastrin response and the G-17 response was assumed to represent non-17 gastrin species, primarily G-34, and a peak concentration of non-17 gastrin $60 \mathrm{~min}$ after the meal is in keeping with this assumption (7). 'Significant differences between women and men. Basal G-17 concentrations were $20 \pm 3$ and $16 \pm 2 \mathrm{pg} / \mathrm{ml}$ in women and men, respectively.
10 , and day 20 of the menstrual cycle. After basal sera were obtained, subjects ate the same meal that had been used in the intragastric experiments (intragastric pH was not controlled and acid secretion not measured in these experiments). Sera were obtained at $30-\mathrm{min}$ intervals for $2 \mathrm{~h}$ after the meal and serum gastrin measured in all specimens in a single separate assay. As shown in Table I, basal and postprandial serum gastrin concentrations did not fluctuate significantly during the menstrual cycle.

\section{G-17 infusion studies}

Clearance of gastrin from circulation. Higher serum gastrin concentrations in women compared with men could have been due to delayed clearance of gastrin. To further evaluate this, serum gastrin concentrations were compared in six women and five men during and after stopping intravenous G-17 infusion $(23.1 \mu \mathrm{g} / \mathrm{h})$. During G-17 infusion, serum gastrin concentrations were nearly identical in women and men (Fig. 3). Moreover, when the G-17 infusion was stopped, the rates of disappearance of gastrin from the circulation were similar (Fig. 3). The disappearance $t_{1 / 2}$ for G-17 averaged $5.7 \pm 0.5 \mathrm{~min}$ in women and $4.5 \pm 0.9 \mathrm{~min}$ in men $(P>0.2)$. These G-17 infusion studies suggest that women do not have a reduced ability to clear a given amount of gastrin from the circulation compared with men.

Parietal cell sensitivity to gastrin. Increased serum gastrin concentrations in women without increased acid secretion suggested that parietal cells in women were less sensitive to gastrin than parietal cells in men. This was evaluated further by comparing serum gastrin concentrations and acid outputs in women and men during intravenous G-17 infusion. As shown in Fig. 4 (left), serum gastrin concentrations in women and men were nearly identical during G-17 infusion. On the other hand, the G-17 dose-acid response curve in women was shifted to the right of the curve in men even when differences in maximal secretory capacity (PAO) were taken into consideration (Fig. 4, right).

TABLE I

Mean ( \pm SE) Basal Serum Gastrin Concentrations and Average Gastrin Rises after a Meal in Six Women Studied throughout One Menstrual Cycle

\begin{tabular}{lcc}
\hline & Basal gastrin & Average gastrin rise $^{\bullet}$ \\
\hline Day 1 & $10 \pm 2$ & $60 \pm 21$ \\
Day 10 & $16 \pm 5$ & $52 \pm 19$ \\
Day 20 & $11 \pm 4$ & $58 \pm 20$ \\
\hline
\end{tabular}

- None of the differences were statistically significant by paired $t$ test.

Sex-related Differences in Gastrin Release 


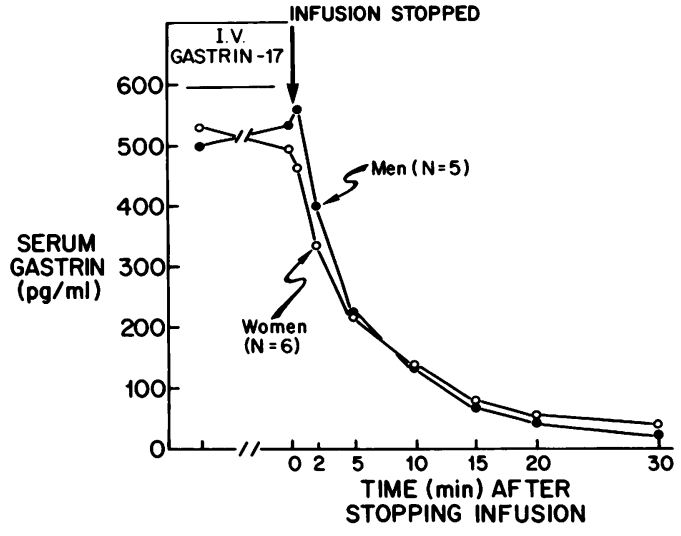

Figure 3 Mean serum gastrin concentrations in six women and five men during and after stopping intravenous G-17 infusion $(23.1 \mu \mathrm{g} / \mathrm{h})$. G-17 was infused for $45 \mathrm{~min}$ and sera were obtained $15 \mathrm{~min}$ before, just before, just after, and 2 , $5,10,15,20$, and $30 \mathrm{~min}$ after stopping the infusion. Serum gastrin concentrations during, at the end of, and after stopping G-17 were nearly identical in women and men.

The dose of G-17 necessary to stimulate half of peak acid secretion $\left(D_{50}\right)$ was estimated from the G-17 doseacid response curve in each subject by extrapolation. Mean and median $\mathrm{D}_{50}$ in women were 7.45 and 5.66 $\mu \mathrm{g} / \mathrm{h}$, respectively, and in men these values were 2.92 and $2.93 \mu \mathrm{g} / \mathrm{h}(P<0.05$, women vs. men). Using the Dowd and Riggs linear transformation of the

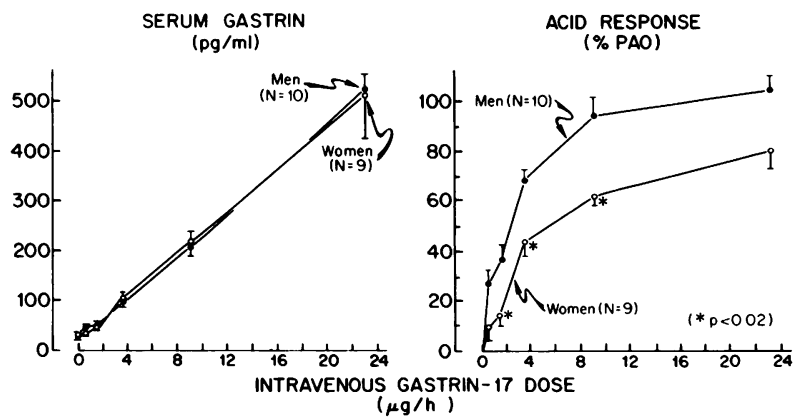

FIGURE 4 Mean serum gastrin concentration (left) and acid response as a percentage of peak acid output (right) during i.v. G-17 infusion in 9 women and 10 men. After $0.15 \mathrm{M}$ $\mathrm{NaCl}$ i.v. was infused for $30-90 \mathrm{~min}$ (control), one of five doses of G-17 was infused intravenously. Two blood samples were obtained for gastrin measurement after $\mathrm{NaCl}$ (basal) or G-17 had been infused for at least $30 \mathrm{~min}$. The relationship between G-17 dose in micrograms per hour (" $X$ ") and serum gastrin in picograms per milliliter (" $Y$ ") was linear and nearly identical in women $(Y=21.2 X+23, r=1.000)$ and men $(Y=21.6 X+22, r=0.999)$. Despite similar serum gastrin concentrations in women and men, acid responses to $G$ 17 were significantly $\left({ }^{\circ} \mathrm{P}<0.02\right)$ less in women than men. Peak acid output in these 9 women and 10 men averaged $30.0 \pm 2.3$ and $33.4 \pm 2.7 \mathrm{mmol} / \mathrm{h}$, respectively.
Michaelis-Menten equation (10), $\mathrm{D}_{50}$ calculated from mean data was $5.47 \mu \mathrm{g} / \mathrm{h}$ in women and $2.25 \mu \mathrm{g} / \mathrm{h}$ in men. Thus, parietal cells in women were approximately half as sensitive to G-17 as parietal cells in men.

\section{DISCUSSION}

These prospective studies were designed because a retrospective analysis of our data collected over the past decade suggested that women had much higher foodstimulated serum gastrin concentrations than men. The results of the prospective study confirmed the finding that women had two- to threefold higher total, G-17, and non-17 gastrin concentrations in the serum after a mixed meal than age-matched men. In contrast, women and men had identical serum gastrin concentrations when equal amounts of human G-17 were infused intravenously and had an equal ability to clear gastrin from the circulation. These data suggest that women had higher gastrin concentrations after a meal because they released more gastrin than men. Because the amount of gastrin released by food is a function of the $\mathrm{pH}$ in the antrum (11), it is important to emphasize that antral $\mathrm{pH}$ was the same, 5.0, in women and men after the meal. Food-stimulated gastrin release in women and men has not been compared previously at a controlled intragastric $\mathrm{pH}$.

Women also had a significantly higher mean basal serum gastrin concentration than men. Two previous studies (one from Norway and one from Greece) have not found statistically significant differences in basal gastrin concentrations between women and men, although mean serum gastrin levels were higher in women than in men in both of those studies $(12,13)$. In fact, in one study mean basal serum gastrin concentrations were $68 \%$ higher in women than men (12) compared with $50 \%$ higher in our study (Fig. 1).

Our conclusion concerning humans differs from a study performed in the rat that found that nonlactating female rats have lower serum and antral gastrin concentrations than male rats (14). In that study, gastrin levels in female rats could be increased to male levels by oophorectomy and then reduced after oophorectomy by estrogen therapy. Gastrin levels in lactating female rats, on the other hand, were higher than gastrin levels in male rats. Differences in gastrin concentrations in rats were attributed to striking differences in food intake (low in female rats, high in male rats, and highest in lactating rats) and in body weight. Our findings in humans lend no support to the hypothesis (14) that reduced PAO and parietal cell mass in women may be due to hypogastrinemia. Our data suggest, in contrast, that women may be relatively resistant to trophic effects of gastrin on parietal cells.

When acid secretory data for each subject were ex- 
pressed as percentage of the individual's PAO in order to correct for differences in parietal cell mass (15), food-stimulated acid secretion was approximately the same in women and men despite two- to threefold elevated serum gastrin (and G-17) concentrations in women. Since G-17 is the major stimulant of acid secretion after protein-containing meals in humans (8), parietal cells in women may have been less sensitive than men to acid stimulation by G-17. The finding that the G-17 dose-response curve for acid secretion in women was shifted to the right of the curve in men and that the $D_{50}$ for G-17 was significantly higher in women than men indicate a relative insensitivity to gastrin in women. Because women and men received the same amount of G-17 and women weighed less than men, women actually received a larger dose of gastrin-17 on a microgram per kilogram basis. Thus, the difference in parietal cell sensitivity to gastrin between women and men would have been even greater than that shown in Fig. 4 if we had expressed our dose as micrograms per kilogram per hour rather than micrograms per hour. We chose to be conservative and express dose as micrograms per hour because serum gastrin levels were the same in men and women when dose was expressed in micrograms per hour (Fig. 4).

Thus, the response of parietal cells to a meal was approximately the same in women and men because of two basic differences that counterbalanced each other (women, high serum gastrin concentration, low parietal cell sensitivity to gastrin; men, low serum gastrin concentration, high parietal cell sensitivity to gastrin). The mechanisms for sex-related differences in gastrin release and target cell sensitivity to gastrin are unknown, although they could be linked in some way. Women have somewhat smaller stomachs than men (16), raising the possibility that the $600-\mathrm{ml}$ meal caused relatively more gastric distention in women than men. However, distention per se is a weak stimulant of gastrin release in humans (9). Moreover, increased distention would be predicted to augment, rather than reduce, sensitivity of parietal cells to gastrin (17). Thus, it is unlikely that different degrees of gastric distention after the meal in women and men explain our findings.

Two primary alterations seem possible as explanations for higher serum gastrin concentrations in women compared with men. First, it is possible that the primary difference is in the acid secretory responsiveness of target cells (presumably parietal cells) to gastrin. This would lead to elevated basal and postprandial serum gastrin concentrations in women due to less acid inhibition of antral gastrin secretion. Primary reduced responsiveness of target cells to gastrin in women could be due to $(a)$ a decrease in a pathway that enhances parietal cell sensitivity to gastrin (e.g., decreased vagal or cholinergic input; decreased histaminergic input); (b) a decrease in the number or affinity of gastrin receptors on target cells; $(c)$ a postreceptor resistance to stimulation by gastrin; or $(d)$ enhancement of a pathway that normally inhibits gastrin-mediated acid secretion. On the other hand, a sex-related difference in gastrin secretion may be the primary alteration. If this were the mechanism, decreased sensitivity of parietal cells to endogenous gastrin in women could be secondary to "down regulation" of the number of gastrin receptors on parietal cells or down regulation of another factor that modulates sensitivity of parietal cells to gastrin. Either primary alteration (differing sensitivity to gastrin; differences in gastrin release) could be due to endocrine factors such as sex steroids. Although we did not correlate acid secretion and gastrin release with serum estrogen, progesterone, or testosterone concentrations, the lack of correlation between gastrin release and the menstrual cycle suggests that fluctuations in the estrogen to progesterone ratio in women may not be of major importance.

Increased parietal cell sensitivity to gastrin and postprandial hypergastrinemia (antral gastrin cell hyperfunction) have been proposed as possible primary abnormalities in patients with duodenal ulcer $(18,19)$. Therapy of duodenal ulcer by vagotomy, on the other hand, reduces parietal cell sensitivity to gastrin, and, secondarily, produces hypergastrinemia $(20,21)$. The present study indicates that "abnormalities" in parietal cell sensitivity to gastrin and postprandial hypergastrinemia may also reflect normal sex-related differences. Thus, enhanced sensitivity to gastrin in male duodenal ulcer patients would be expected if compared to a mixed (male and female) control population. Likewise, increased postprandial gastrin secretion would not be surprising in female relatives of any duodenal ulcer patient. Therefore, it is necessary to carefully control for sex when studying the role of gastrin in the pathophysiology of duodenal ulcer. It is possible that some females with duodenal ulcer will be shown to have acid hypersecretion because they have lost their "normal" insensitivity to gastrin and that some men with duodenal ulcer will be shown to have acid hypersecretion because they release large amounts of gastrin after a meal, amounts of gastrin similar to those released by women.

Because of their relative insensitivity to acid stimulation by gastrin, women may be protected, to some extent, against the effects of markedly elevated serum gastrin concentrations. This may explain why the Zollinger-Ellison syndrome (islet cell tumor, hypergastrinemia, acid hypersecretion, peptic ulcer disease) is half as common in women as in men (22-24), even though islet cell tumors occur at autopsy with equal frequency in both sexes (25). 


\section{ACKNOWLEDGMENTS}

The authors wish to thank Tina Barnett, June Ferrarri, Mary Walker, Mary Matasso, and Kathy Cooper for excellent technical help, Pat Ladd for illustrations, and Vicky Usry for preparing the manuscript. The authors would also like to thank John S. Fordtran, M.D. and Michael R. Vasko, Ph.D. for their many helpful suggestions.

This work was supported by grants AM16816, AM17328

(to the Center for Ulcer Research and Education) and AM17294 from the National Institute of Arthritis, Metabolism, and Digestive Diseases.

\section{REFERENCES}

1. Moore, E. W., and R. W. Scarlata. 1965. The determination of gastric acidity by the glass electrode. Gastroenterology. 49: 178-188.

2. Feldman, M. 1979. Comparison of acid secretion rates measured by gastric aspiration and by in vivo intragastric titration in healthy human subjects. Gastroenterology. 76: 954-957.

3. Multicenter Study. 1969. Intramuscular pentagastrin compared with other stimuli as tests of gastric secretion. Lancet. I: 341-343.

4. Fordtran, J. S., and J. H. Walsh. 1973. Gastric acid secretion rate and buffer content of the stomach after eating. Results in normal subjects and in patients with duodenal ulcer. J. Clin. Invest. 52: 645-657.

5. Walsh, J. H., J. I. Isenberg, J. Ansfield, and I. V. Maxwell. 1976. Clearance and acid-stimulating action of human big and little gastrins in duodenal ulcer subjects. J. Clin. Invest. 57: 1125-1131.

6. Walsh, J. H. 1974. Radioimmunoassay of gastrin. In Nuclear Medicine In Vitro. B. Rothfield, editor. J. B Lippincott, Philadelphia. pp. 231-248.

7. Dockray, G. J., and I. L. Taylor. 1976. Heptadecapeptide gastrin. Measurement in blood by specific radioimmunoassay. Gastroenterology. 71: 971-977.

8. Feldman, M., J. H. Walsh, H. C. Wong, and C. T. Richardson. 1978. Role of gastrin heptadecapeptide in the acid secretory response to amino acids in man. J. Clin. Invest. 61: 308-313.

9. Richardson, C. T., J. H. Walsh, M. I. Hicks, and J. S. Fordtran. 1976. Studies on the mechanisms of food-stimulated gastric acid secretion in normal human subjects. J. Clin. Invest. 58: 623-631.

10. Grossman, M. I. 1973. What do you do with basal in dose-response studies? Gastroenterology. 65: 341-344.

11. Walsh, J. H., C. T. Richardson, and J. S. Fordtran. 1975. $\mathrm{pH}$ dependence of acid secretion and gastrin release in normal and ulcer subjects. J. Clin. Invest. 55: 462-468.
12. Gedde-dahl, D. 1974. Radioimmunoassay of gastrin. Fasting serum levels in humans with normal and high gastric acid secretion. Scand. J. Gastroenterol. 9: 41-47.

13. Archimandritis, A., G. Alegakis, G. Theodoropoulos, A. Kalos, G. Drivas, and K. Melissinos. 1979. Serum gastrin concentration in healthy males and females of various ages. Acta Hepato-Gastroenterol. 26: 58-63.

14. Lichtenberger, L. M., D. M. Nance, and R. A. Gorski. 1976. Sex-related differences in antral and serum gastrin levels in the rat. Proc. Soc. Exp. Biol. Med. 151: 785788.

15. Card, W. I., and I. N. Marks. 1960. The relationship between the acid output of the stomach following " $\max$ imal" histamine stimulation and the parietal cell mass. Clin. Sci. 19: 147-163.

16. Cox, A. J. 1952. Stomach size and its relation to chronic peptic ulcer. A.M.A. Arch. Pathol. 54: 407-422.

17. Grossman, M. I. 1981. Regulation of gastric acid secretion. In Physiology of the Gastrointestinal Tract. L. R. Johnson, editor. Raven Press, New York. 23: 659-671.

18. Lam, S. K., J. I. Isenberg, M. I. Grossman, W. H. Lane, and J. H. Walsh. 1980. Gastric acid secretion is abnormally sensitive to endogenous gastrin released after peptone test meals in duodenal ulcer patients. J. Clin. Invest. 65: 555-562.

19. Taylor, I. L., J. Calam, J. I. Rotter, C. Vaillant, I. M. Samloff, A. Cook, E. Simkin, and G. J. Dockray. 1981. Family studies of hypergastrinemic, hyperpepsinogenemic I duodenal ulcer. Ann. Intern. Med. 95: 421-425.

20. Elder, J. B., G. Gillespie, E. H. G. Campbell, I. E. Gillespie, G. P. Crean, and A. W. Kay. 1972. The effect of vagotomy on the lower part of the acid dose-response curve to pentagastrin in man. Clin. Sci. 43: 193-200.

21. Feldman, M., R. M. Dickerman, R. N. McClelland, K. A. Cooper, J. H. Walsh, and C. T. Richardson. 1979. Effect of selective proximal vagotomy on food-stimulated gastric acid secretion and gastrin release in patients with duodenal ulcer. Gastroenterology. 76: 926-931.

22. Ellison, E. H., and S. D. Wilson. 1964. The ZollingerEllison syndrome: reappraisal and evaluation of $260 \mathrm{reg}$ istered cases. Ann. Surg. 160: 512-528.

23. Stage, J. G., and F. Stadil. 1979. The clinical diagnosis of the Zollinger-Ellison syndrome. Scand. J. Gastroenterol. 14(Suppl 53): 79-91.

24. Bonfils, S., J. H. Landor, M. Mignon, and P. Hervoir. 1981. Results of surgical management in 92 consecutive patients with Zollinger-Ellison syndrome. Ann. Surg. 194: 692-697.

25. Lopez-Kruger, R., and M. B. Dockerty. 1947. Tumors of the islets of Langerhans. Surg. Gynecol. and Obstet. 85: 495-511. 